\title{
TINGKAT KELAINAN SEL PURKINJE HETEROTOPIK HUBUNGANNYA DENGAN PERBEDAAN SENSITIVITAS ANTARA LOBUS ANTERIOR DAN POSTERIOR DARI CEREBELLUM TIKUS TERHADAP RADIASI SINAR-X
}

\author{
Win Darmanto \\ Jurusan Biologi FMIPA Universitas Airlangga
}

\begin{abstract}
Our previous experiment showed that prenatal exposure of rats to X-radiation in the late gestation period causes heterotopic Purkinje cells in the internal granular layer (IGL) of the cerebellum. The present study demonstrated precisely the involvement of Reelin in the aligment of Purkinje cells, which are different in severity between anterior and posterior lobes. Pregnant rats were exposed to 2.5 Gy X-radiation on gestation day 21 and the cerebellum of progeny was examined histologically and by immunohistochemistry of IP3 Receptor to identify Purkinje cells. By P8, while Purkinje cells with well developed dendrites aligned underneath the EGL in the control cerebellum, Purkinje cells with shorter and abnormally oriented dendrites failed to align and remained in the heterotopic location in the IGL of the anterior lobes but a small number of heterotopic Purkinje cells formed in the posterior lobes of the irradiated rats. Our previous published Reelin is present in the premigratory zone of the EGL and IGL in the control cerebellum. It decreased in the irradiated cerebellum on $P 1$ to P8, especially the anterior lobes, however in posterior lobes on P8 Reelin level compared to the control (Darmanto, 2003). It is thus indicated that anterior lobes are more sensitive to X-radiation than posterior lobes and the different levels of Reelin between anterior and posterior lobes caused by X-irradiation may contribute the different susceptibility in induction of deranged Purkinje cells.
\end{abstract}

Key words: cerebellum, heterotopic, Purkinje cell, X-irradiation

\section{PENGANTAR}

Tikus pada masa akhir kebuntingan diradiasi dengan sinar-X dapat menyebabkan sel Purkinje di cerebellum salah letak (heterotopik) (Darmanto et al., 1998; Darmanto et al., 2000). Kami juga telah mendemonstrasikan bahwa protein ekstrasellular Reelin bertanggung jawab pada proses terjadinya sel Purkinje heterotopik (Darmanto et al., 2000). Walaupun sel Purkinje heterotopik dan pola foliasi cerebellum abnormal telah dilaporkan lebih tampak jelas di bagian anterior daripada posterior dari cerebellum (Darmanto et al., 2000), namun mekanisme perbedaan kepekaan antara anterior dan posterior dalam memunculkan sel Purkinje heterotopik akibat radiasi sinar-X belum pernah diungkapkan dan dipublikasikan. Penelitian ini bertujuan untuk menjelaskan perbedaan proses terjadinya sel Purkinje heterotopik antara bagian lobus anterior dan lobus posterior dari cerebellum, kaitannya dengan perbedaan ekspresi protein Reelin yang berbeda antara lobus anterior dan posterior dari cerebellum.

Calon sel Purkinje lahir dari bagian otak (neuroepithelium) dari rhombic lip pada tahap awal neurogenesis, yaitu sekitar umur kebuntingan 12-15 hari pada tikus (Altman and Bayer, 1978). Calon sel Purkinje bermigrasi dari daerah ventrikel secara radial menuju permukaan luar cerebellum (Yuasa et al., 1991). Pada cerebellum normal sel Purkinje membentuk monolayer tepat di bawah external granular layer (EGL), dan percabangan dendrit berkembang di dalam molecular layer (ML). Di sisi lain, sel granulosa yang berada di bagian kortek bermitosis dan mensintesis Reelin, selanjutnya bermigrasi ke arah dalam yaitu internal granular layer (IGL) melalui ML dan Purkinje Cell Layer (PCL). Reelin adalah salah satu protein ekstrasellular yang disekresi oleh sel granulosa saat awal migrasi dan berfungsi sebagai matrix adhesion molecule yang membantu pengaturan pola posisi sel saraf (Goffinet, 1995).

Pada penelitian kami sebelumnya menunjukkan bahwa kerusakan sel granulosa di daerah EGL setelah radiasi sinar$\mathrm{X}$, dan tingkat ketebalan hasil pemulihan EGL dan ekspresi Reelin terjadi sangat bervariasi antara lobus anterior dan lobus posterior. Bagian anterior ekspresi protein Reelin lebih rendah dari pada bagian posterior hal ini seiring dengan ketebalan sel granulose di bagian EGL dari lobus anterior lebih tipis (Darmanto, 2003). Hasil ini membuktikan bahwa ekspresi protein Reelin yang rendah di bagian lobus anterior menghasilkan jumlah sel Purkinje yang mengalami heterotopik lebih banyak di bagian anterior daripada lobus posterior. Penelitian ini menduga protein Reelin benar-benar berperan penting dalam proses penempatan sel Purkinje dan bertanggung jawab terhadap terjadinya perbedaan sel Purkinje heterotopik antara lobus anterior dan lobus posterior. 


\section{BAHAN DAN CARA KERJA}

\section{Bahan Penelitian}

Tikus putih bunting strain Std: Wistar/ST, sebanyak 20 ekor terdiri atas lima induk mencit kontrol dan 15 induk mencit perlakuan, ditempatkan dalam kandang terbuat dari stainless steel diletakkan dalam rumah hewan dengan kondisi ruang ber-AC, temperatur $\left(21 \pm 1^{\circ} \mathrm{C}\right)$, kelembaban relatif $(50 \pm 10 \%)$ dan jadwal perubahan gelap/terang selama 12 jam. Tikus diberi makanan standart (CE-2, CLEA, Japan) dan air minum ad libitum.

\section{Cara Kerja}

Tikus putih umur kebuntingan 21 hari (ditemukan vaginal plug dianggap umur kebuntingan 0 hari). Pada pukul 8.00 tikus bunting diradiasi dengan sinar-X pada seluruh tubuhnya dengan dosis 2,5 Gy. Faktor radiasi adalah $140 \mathrm{kVp}, 5 \mathrm{~mA}, 0,5 \mathrm{~mm} \mathrm{Cu} \pm 0,5 \mathrm{~mm}$ Al sebagai filtrasi, dan laju radiasi 104,0 \pm 0,5 $\mathrm{mGy} / \mathrm{min}$. Untuk memperoleh distribusi dosis yang merata, tikus ditempatkan pada kotak plastik di atas papan yang dapat berputar selama irradiasi dengan kecepatan 4 rpm. Tikus dibiarkan melahirkan dan menyusui anaknya. Anak tikus baik kontrol maupun irradiasi dibunuh dengan cara dianesthesi dengan diethyl ether, diperfusi melalui jantung dengan larutan formaldehyde 4\%, selanjutnya difiksasi dengan larutan yang sama selama semalam. Pengambilan cerebellum pada anak tikus dilakukan setiap hari mulai dari anak tikus baru lahir (P0) sampai anak tikus umur 16 hari atau Postnatal day 16 (P16) dan dewasa. Setelah difiksasi, cerebellum didehidrasi, embeding dengan parafin dan dibuat sayatan secara berseri pada posisi mid-saggital dengan ketebalan $5 \mathrm{~mm}$. Sayatan tersebut diwarnai dengan hematoksilin dan eosin (HE) dan dilakukan pemeriksaan immunohistokimia.

Pemeriksaan secara immunohistokimia digunakan antiinositol 1,4,5-triphosphate (IP3) receptor, untuk mendeteksi sel Purkinje. Pemeriksaan secara immunohistokimia diambil 2 sampai 3 sayatan untuk setiap cerebellum yang dipilih dari rangkaian pita sayatan. Sayatan dimasukkan larutan xylene untuk mengeluarkan parafin, rangkaian alkohol dengan konsentrasi berseri untuk tujuan hidrasi, dan diinkubasi ke dalam rangakaian larutan sebagai berikut: (1) methanol $80 \%$ yang mengandung $0,6 \% \mathrm{H}_{2} \mathrm{O}_{2}$; (2) 0,1 M phosphate-buffered saline (PBS), pH 7,0 mengandung $0,3 \%$ Triton X-100 selama 30 menit; (3) 10\% serum kambing normal pada temperatur kamar selama 10 menit; (4) anti IP3 receptor antibody, 4C11 (Maeda, 1988) diencerkan dalam PBS sebesar 1 : 100, diletakkan pada temperatur $4^{\circ} \mathrm{C}$ selama semalam; (5) biotinylated universal secondary antibody (Vector Laboratories, Burlingame, CA) pada temperatur kamar selama 30 menit; (6) peroxidaseconjugated streptavidin (Vector Laboratories) pada temperatur kamar selama 50 menit; dan (7) 0,02\% larutan diaminobenzidine/DAB (Vector Laboratories) dan 0,006\% $\mathrm{H}_{2} \mathrm{O}_{2}$ pada temperatur kamar selama 5-10 menit. Sayatan selanjutnya dilakukan dehidrasi dengan rangkaian alkohol berseri, dan mounting (penutupan dengan cover glass). Sayatan yang telah kering diamati dengan mikroskop cahaya (Darmanto et al., 2000).

\section{HASIL}

Hasil pengamatan pada sayatan secara mid-saggital di bagian vermis dari cerebellum anak tikus sebagai efek akut dari radiasi sinar- $\mathrm{X}$, terlihat adanya kerusakan sel granulosa yang terjadi di daerah EGL saat 6 jam setelah diradiasi. Namun sel Purkinje menunjukkan terlihat resisten terhadap radiasi sinar-X. Dari hasil penelitian sebelumnya menunjukkan bahwa kematian sel di bagian lobus posterior (posterior sampai fissura secunda) lebih rendah daripada di bagian lobus anterior (Darmanto, 2003). Selang waktu 3 hari setelah radiasi (umur 2 hari), jumlah sel hidup di bagian lobus posterior lebih besar sekitar 2-3 lapis sel, sedang di bagian lobus anterior jumlah sel granulosa hidup antara 0-2 lapis sel (Gambar 1). Setelah anak tikus umur 5 hari, pemulihan sel granulosa mulai terlihat jelas, di bagian lobus posterior pemulihan terlihat lebih cepat dari pada lobus anterior. Sedang di bagian anterior pemulihan tersebut sangat bervariasi yaitu antara 1-4 lapis sel granulosa (Gambar 1). 

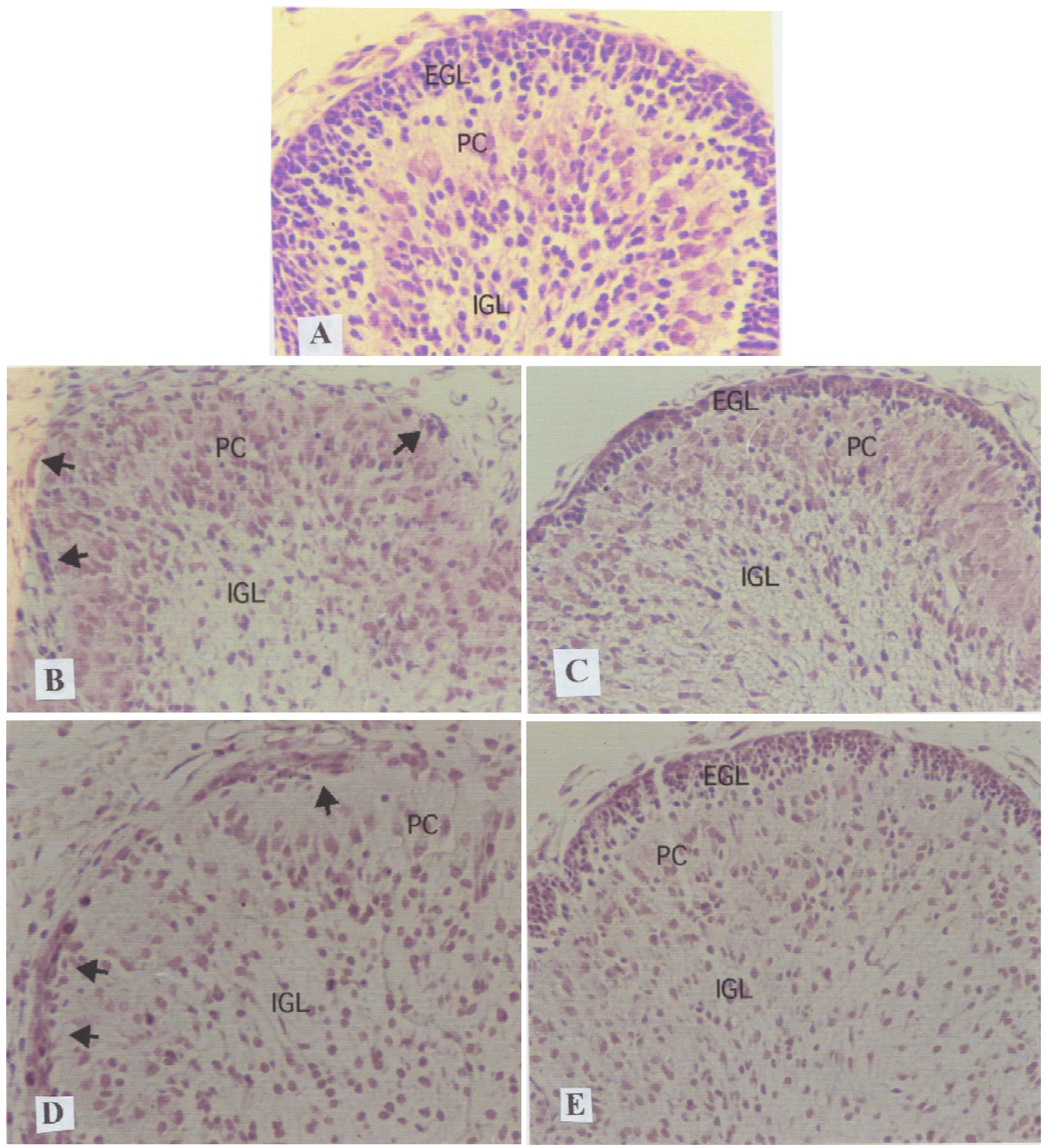

Gambar 1. Kerusakan jaringan akibat radiasi sinar-X, diamati dengan perwarnaan hematoksilin eosin pada bagian cerebellum anak mencit. A: Cerebellum anak tikus kontrol, sel granulosa tersusun antara 5-9 sel. B: Lobus anterior cerebellum anak tikus 2 hari setelah irradiasi, hampir seluruh sel granulosa di EGL mengalami kematian sehingga hanya tersisa beberapa sel granulosa (anak panah). C: Lobus posterior, sel granulosa di EGL terlihat lebih banyak yaitu antara 3-5 lapis sel. D: Lobus anterior cerebellum anak tikus umur 5 hari beberapa sel granulosa telah mengalami pemulihan (anak panah). E: Lobus posterior, sel granulosa telah sempurna mengalami pemulihan bila dibandingkan dengan bagian anterior. EGL: external granular layer; IGL: internal granular layer, PC: Purkinje cell. Garis skala = $150 \mathrm{~mm}$ 
sel Purkinje kontrol telah berkembang dengan percabangan dendritik mengarah ke permukaan (Gambar 2A). Pada anak tikus irradiasi, di bagian lobus anterior, beberapa sel Purkinje heterotopik di daerah IGL dengan susunan 2-4 lapis sel, dengan dendrite tumbuh tidak normal, yaitu terlihat dendrite utama pendek dengan percabangan sedikit, beberapa mempunyai orientasi terbalik (Gambar2B). Pengamatan pada lobus posterior, jumlah sel Purkinje yang mengalami heterotopik lebih kecil, yaitu sekitar 1-2 lapis sel (Gambar 2C).

Pada penelitian ini kami mengamati adanya perbedaan kelainan secara patologi pada cerebellum anak tikus akibat radiasi sinar-X masa prenatal antara lobus anterior dan lobus posterior.

\section{PEMBAHASAN}

Radiasi sinar-X menyebabkan kematian sel granulosa sebagai efek akut, selanjutnya diikuti proses pemulihan EGL. Namun di daerah poserior pemulihan EGL lebih cepat dibandingkan lobus anterior. Walaupun sel Purkinje resisten terhadap sinar-X, mereka menunjukkan posisi yang tidak teratur dengan pertumbuhan dendrit tidak normal. Ketidakteraturan posisi sel Purkinje bersifat permanen di bagian anterior, tetapi di bagian posterior menunjukkan adanya pemulihan, sehingga akhirnya menyerupai kontrol.

Untuk mengetahui mekanisme terjadinya perbedaan tingkat molekular tentang pola sel Purkinje heterotopik antara bagian anterior dan posterior, juga diamati ekspresi protein Reelin dengan menggunakan imunoflourescence terhadap CR-50 (Darmanto, 2003). Ekspresi Protein Reelin di bagian anterior juga terlihat lebih rendah, di mana pemulihan EGL juga lebih rendah bila dibandingkan dengan lobus posterior. Hasil ini menunjukkan bahwa jika jumlah sel granulosa hasil proses pemulihan kecil, maka ekspresi Reelin juga rendah dan diduga selanjutnya mengakibatkan sel Purkinje heterotopik.

Proetin Reelin adalah salah satu kelompok protein ekstrasellular yang disintesis oleh sel granulosa dan telah diketahui berperan dalam membantu dalam proses adhesi dan migrasi sel neuron pada tahap perkembangan otak (Ogawa et al., 1995; D’Arcangelo et al., 1995; Miyata et al., 1997). Pada mencit mutan reeler, yang mana Reelin tidak disintesis, sel Purkinje tidak bermigrasi sehingga tinggal membentuk gerombolan di daerah deep cerebellar (Yoneshima et al., 1997; Goldowitz et al., 1997; Tromsdorff et al., 1999; Hirotsune et al., 1995). Hasil ini menyimpulkan bahwa Reelin benar-benar berperan dalam migrasi sel Purkinje. Immunoflourescence terhadap Reelin seperti yang dipublikasikan sebelumnya (Darmanto, 2003), secara jelas mendemostrasikan bahwa radiasi sinar-X pada umur kebuntingan 21 hari menyebabkan penurunan protein Reelin mulai saat 48 jam setelah radiasi sampai anak tikus umur 8 hari, khususnya di bagian anterior. Di bagian posterior ekspresi protein Reelin mengalami pemulihan pada umur 5 hari. Dari hasil ini terlihat adanya indikasi bahwa menurunnya kadar Reelin yang terjadi pada masa kritis yaitu saat sel purkinje membentuk susunan satu lapis sel, akan menyebabkan sel Purkinje heterotopik. Oleh karena itu, hasil ini dapat digunakan sebagai fakta tambahan untuk memperjelas hasil penelitian kami sebelumnya (Darmanto et al., 2000), bahwa Reelin berfungsi sangat penting dalam penyusunan posisi sel Purkinje.

Perbedaan sensitivitas antara lobus anterior dan posterior dari cerebellum mencit juga telah diamati pada beberapa mencit mutan, di mana ada perbedaan pola ekspresi gen antara lobus anterior dan posterior (Herrup and Kuemerle, 1997; Miyata et al., 1999). Adanya perbedaan yang nyata antara lobus anterior dan posterior juga telah diamati pada kelainan mutasi yang melibatkan kematian sel granulosa pada beberapa mencit mutan, yaitu pada mencit leaner (tgla/tgla) (Herrup and Wilczynski, 1982) dan meander tail (mea/mea) (Ross et al., 1990; Hamre and Goldowitz, 1997). Pada kedua mencit mutan leaner dan meander tail, kematian sel granulosa lebih banyak terjadi di lobus anterior dari pada posterior (Herrup and Wilczynski, 1982; Ross et al., 1990; Hamre and Goldowitz, 1997). Kami menduga bahwa perbedaan resistensi di bawah pengaruh regulasi gen seperti adanya perbedaan regional pada cerebellum. Alasan lain yaitu pada bagian anterior dari cerebellum secara phylogenetic dibentuk lebih awal dari pada bagian posterior (Larsell, 1967), dari alasan ini diduga, bagian yang muda lebih sensitif dari bagian yang lebih tua, seperti pada kelainan korteks cerebral akibat radiasi sinar-X (Tamaki and Inouye, 1979). Dengan menggunakan radiasi sinar X untuk menginduksi kematian sel granulosa, hasil kami juga mendukung adanya perbedaan resistensi kompartmentalisasi antara anterior dan posterior pada cerebellum (Darmanto, et al., 1997).

Sebagai ringkasan, penelitian ini mendemonstrasikan bahwa radiasi sinar X pada saat perkembangan cerebellum yaitu saat umur kebuntingan ke-21 hari, menyebabkan kematian sel granulosa di EGL lebih banyak di bagian lobus anterior daripada bagian posterior, dan mengakibatkan pembentukan sel Purkinje heterotopik lebih banyak di bagian lobus anterior, hal ini diduga ada kaitannya dengan ekspresi protein Reelin yang juga rendah di bagian anterior daripada lobus posterior. 


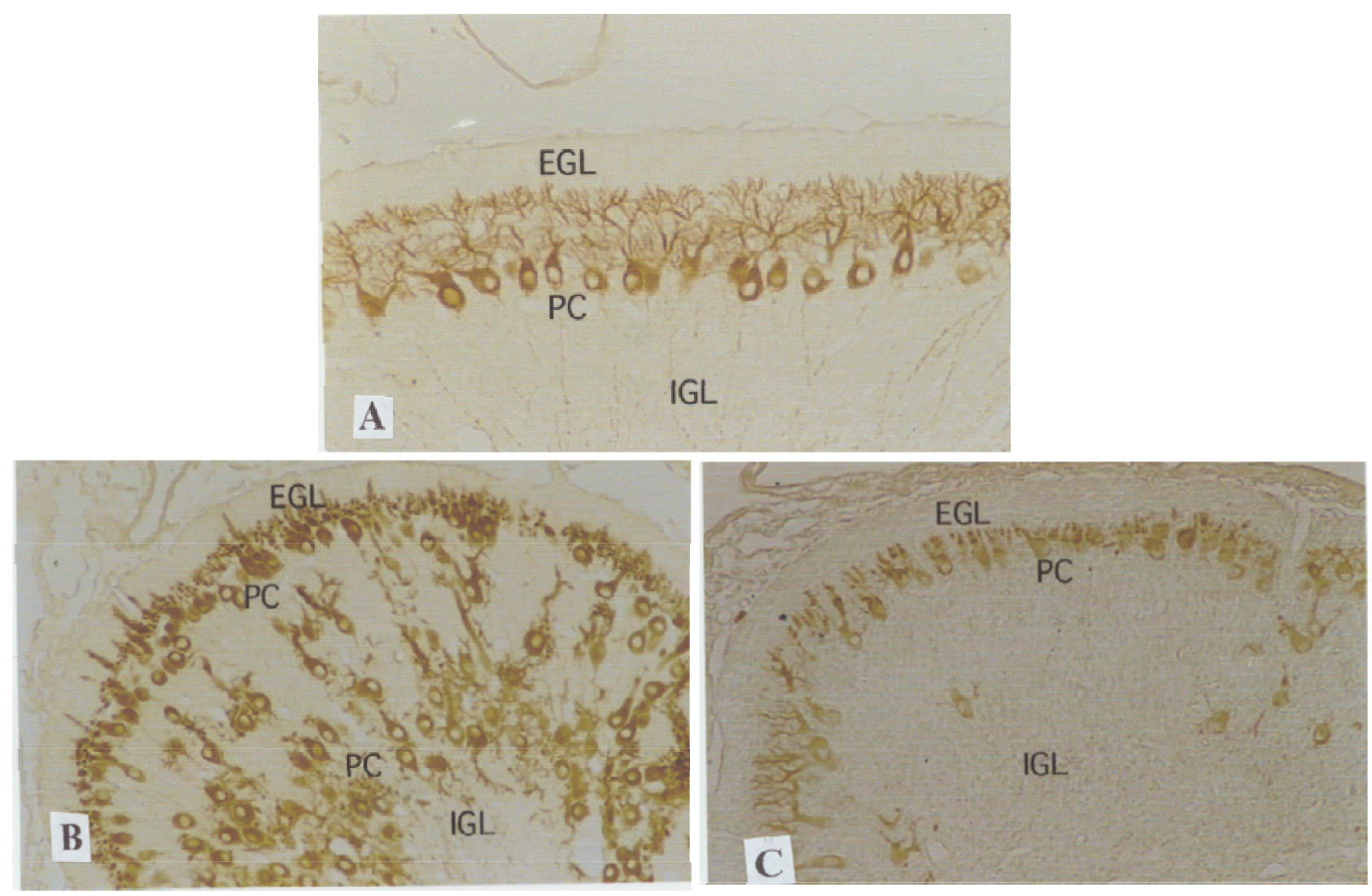

Gambar 2. Immunohistokimia terhadap IP3 receptor pada anak mencit umur 8 hari. A: Cerebellum mencit kontrol, susunan sel Purkinje membentuk satu deret sel dengan dendrite tumbuh normal. B: Lobus anterior dari cerebellum tikus irradiasi, sel Purkinje tersusun beberapa lapis sel, sebagian heterotopik di daerah IGL, dengan dendrite tidak tumbuh sempurna, beberapa dendrite mempunyai arah terbalik. C: Lobus posterior, sel Purkinje yang mengalami heterotopik jumlahnya lebih sedikit. Perbesaran 500×. EGL : external granular layer; PCL: Purkinje cell layer; IGL: internal granular layer. Garis skala $=150 \mathrm{~mm}$

Seperti yang kami demonstrasikan pada penelitian sebelumnya bahwa Reelin berperan penting dalam penyusunan posisi sel Purkinje (Darmanto et al., 2000). Penelitian ini menyimpulkan bahwa perbedaan sel Purkinje heterotopik antara lobus anterior dan posterior sebagai akibat dari kerusakan sel granulosa lebih parah di bagian anterior daripada posterior.

Saran yang perlu dipertimbangkan adalah; untuk memperkuat adanya anggapan terhadap peran protein Reelin dalam penempatan sel Purkinje pada cerebellum, masih ada satu cara pembuktian lagi yaitu, transplantasi jaringan yang secara normal mengekspresi Reelin ke dalam bagian anterior dari cerebellum yang mengalami penurunan ekspresi Reelin. Selanjutnya diamati perkembangan sel Purkinje di daerah transplantasi.

\section{UCAPAN TERIMA KASIH}

Penelitian ini dikerjakan di Department of Genetics and Teratology, Research Institute of Environmental Medicine,
Nagoya University di bawah bimbingan Prof. Dr. Yoshiharu Murata dan Dr. Minoru Inouye, biaya penelitian didanai oleh Monbusho dan Department of Genetics and Teratology. Pada kesempatan ini dengan penuh rasa hormat, saya mengucapkan banyak terima kasih pada kedua pembimbing di atas dan segenap staf di Departement of Genetics and Teratology. Terima kasih juga saya sampaikan kepada Prof. Dr. Masharu Ogawa, Brain Science Institute, RIKEN, Saitama; Prof. Dr. Katshuhiko Mikoshiba, The Institute of Medical Science, The University of Tokyo, Japan, atas sumbangan anti bodi IP3 receptor dan anti CR50; dan Pemerintah Jepang yang telah membantu dan memberi kesempatan saya untuk melakukan penelitian ini.

\section{DAFTAR PUSTAKA}

Altman J and Bayer SA, 1978. Prenatal development of the cerebellar system in the rat II. Cytogenesis and histogenesis of the inferior olive, pontine gray and the precerebellar reticular nuclei. Journal of Comparative Neurology. 179: 49-76. 
Darmanto W, 2003. Perbedaan ekspresi protein reelin antara lobus anterior dan posterior dari cerebellum tikus putih akibat radiasi sin ar-x m as a p ralan ir. Journal of Mathematics and Science. 8(2): 105-110.

Darmanto W, Inouye M, Takagishi Y, Ogawa M, Mikoshiba K, and Murata Y, 2000. Derangement of Purkinje cells in the rat cerebellum following prenatal exposure to X-irradiation: Decreased Reelin level is possible cause. Journal of Neuropathology and Experimental Neurology. 59: 245-256.

Darmanto W, Inouye M, Hayasaka S, Takagishi Y, Aolad HM, and Murata Y, 1998. Dose response relationship of disturbed migration of Purkinje cells in the cerebellum due to X-irradiation. Environmental Medicine. 42: 46-50.

Darmanto W, Hayasaka S, Takagishi Y, Aolad HM, and Inouye M, 1997. Sensetivity difference between anterior and posterior lobes of rat cerebellum to prenatal exposure to 2.5 Gy X-irradiation: A histological study. Environmental Medicine. 41: 93-96.

D’Arcangelo G, Miao GG, Chen SC, Soares HD, Morgan JL, and Curran T, 1995. A Protein related to extracellular matrix proteins deleted in the mouse mutant reeler. Nature. 374 : 719-723.

Goldowitz D, Cushing RC, and Laywell E, 1997. Cerebellar disorganization characteristic of reeler in scrambler mutant mice despite presence of Reelin. Journal of Neuroscience. 17: 8767-8777.

Goffinet AM, 1995. A real gene for reeler. Nature. 374: 675-676.

Hamre KM and Goldowitz D, 1997. Meander tail acts intrinsic to granule cell precursors to discrupt cerebellar development: analysis of meander tail chimeric mice. Development. 124: 4201-4212.

Herrup K and Kuemerle B, 1997. The compartmentalization of the cerebellum. Annual Review Neuroscience. 20: 61-90.

Herrup K and Wilczynski S, 1982. Cerebellar cell degeneration in the leaner mutant mouse. Neuroscience. 7: 2185-2196.

Hirotsune S, Takahara T, Sasaki N, Yoshiki A, Ohashi T, Kusabake M, Murakami Y, Muramatsu M, Watanabe S, Nakao K, Katsuki M, and Hayashizaki Y, 1995. The reeler gene encodes a protein with an EGF-like motif expressed by pioner neurons. Nature Genetics. 10: 77-83.
Larsel O, 1967. The Comparative Anatomy and Histology of Cerebellum from Myxinoids through Birds, $1^{\text {st }}$ ed.Mineanpolis: The University of Minnesota Press.

Maeda N, Ninobe M, Nakahira K, and Mikoshiba K, 1988. Purification and characterization of $\mathrm{P} 400$ protein, a glycoprotein caracteristic of Purkinje cell, from mouse cerebellum. Journal of Neurochemestry. 51: 1724-1730.

Miyata T, Maeda T, and Lee JE, 1999. NeuroD is required for differentiation of the granule cells in the cerebellum and hipocampus. Gen Development. 3: 1647-1652.

Miyata K, Nakajima K, Mikoshiba K, and Ogawa M, 1997. Regulation of Purkinje cell aligment by Reelin as revealed with CR-50 antibody. Journal of Neuroscience. 17: 35993609.

Ogawa M, Miyata T, and Nakajima K, 1995. The reeler gene-associated antigen on Caja-Retzius neurons is a crusial molecule for laminar organization of cortical neurons. Neuron. 14: 899-912.

Ross ME, Fletcher C, Mason CA, Hatten ME, and Heintz N, 1990. Meander tail reveals a developmental unit in mouse cerebellum. Proceeding Nature Academic Science. 87: 4189-4192.

Tamaki M and Inouye M, 1979. Avoidence of and anticipatory response to shock in prenatally $\mathrm{X}$-irradiated rats. Physiology of Behavior. 22: 701-705.

Tromsdorff M, Gotthardt M, and Hieberger T, 1999. Reeler/ Disabled-like disruption of neuronal migration in knockout mice lacking the VLDL receptor and ApoE receptor 2. Cell. 97: 689-701.

Yoneshima H, Nagata E, Matshumoto M, Yamada M, Nakajima K, Miyata T, and Ogawa M, 1997. A novel neurological mutant mouse, yotari, which exhibits reeler like phenotype but expresses CR-50 antigen Reelin. Neuroscience Research. 29: 217-223.

Yuasa S, Kawamura K, Ono K, Yamakuni T, and Takahashi Y, 1991. Development and migration of Purkinje cells in the mouse cerebellar primordium. Anatomy Embryology. 184: 195-212.

Reviewer: Prof. Dr. Sutiman B Sumitro 